\title{
Immune Regulation in Allergic and Irritant Skin Reactions
}

\author{
Ole Baadsgaard, M.D., and Timothy Wang, B.S.
}

Contact dermatitis is an inflammatory response of the skin characterized by dermal perivascular and epidermal mononuclear cell infiltration, spongiosis, and hyperplasia. Often a result of insult by antigen or irritant, it is caused by an upset in the normal balance of immunoregulatory signals from both resident and nonresident cells. $T$ cells, which continuously traffic through the skin, are central to the skin's immunoregulation. Their activation and subsequent lymphokine release are critical events in the development of an inflammatory immune reaction.

Activation of $\mathrm{T}$ lymphocytes can occur via either antigen-dependent or antigen-independent pathways. Antigen-dependent recognition is critical to allergic contact dermatitis reactions, whereas antigen-independent pathways seem important in irritant-induced contact dermatitis. Langerhans cells are the only antigen-presenting cells constitutively found in the epidermis. They present antigen to $\mathrm{T}$ cells, thereby eliciting T-cell activation and providing positive signals for upregulation of the immune response. Conversely, other epidermal antigen-presenting cell (APC) subtypes that migrate into the epidermis during an allergic contact dermatitis reaction may activate suppressor pathways, thus downregulating the immune reaction. Keratinocytes, which comprise approximately $90 \%$ of the total epidermal cell population, are not passive bystanders in the immune response and can transmit both positive and negative signals. Thus, they may function as a modulator of the immune system, up- or downregulating T-cell responses. Injury- or irritant-activated keratinocytes can elaborate factors and cytokines that may be responsible for antigen-independent $\mathrm{T}$-cell activation and lymphokine release resulting in

From the Department of Dermatology, Immunodermatology Unit, University of Michigan Medical School, Ann Arbor, Michigan.

Supported in part by the Babcock Foundation.

Address correspondence to: Ole Baadsgaard, M.D., Gentofte Hospital, Department of Dermatology, Neils Andersenvej 65, Hellerup, Denmark 2900. an inflammatory skin reaction. The cellular interactions and the mechanisms that govern them in the development of both allergic and irritant contact dermatitis form the focus of this review.

\section{Epidermal Immunocompetent Cells}

To understand the pathogenetic mechanisms involved in contact dermatitis, it is important to appreciate the different immunocompetent cells of the skin. The epidermis represents the outermost boundary of the immune system and is composed mainly of keratinocytes, Langerhans cells, and melanocytes. Keratinocytes and Langerhans cells are known to be immunocompetent; however, the immunologic function of melanocytes, if any, is not clear.

The keratinocyte's role in the immunoregulation of the skin has only recently been appreciated. The first indication of its immunocompetent nature was the unexpected discovery in the early 1980 s by Luger et al. and Sauder et al. of a keratinocyte-derived cytokine, epidermal cell-derived thymocyte activating factor (ETAF). ${ }^{1,2}$ The majority of ETAF activity was later found to be due to interleukin-1 (IL-1). As keratinocytes were investigated more widely, it became clear that activated keratinocytes have the ability to produce a variety of distinct $T$-cell-activating and growth-stimulating cytokines. ${ }^{3,4}$ Others include interleukin-3 (IL-3), ${ }^{5,6}$ granulocyte macrophage colony stimulating factor (GM-CSF), ${ }^{7}$ epidermal cell-derived natural killer cell activating factor (ENKAF) ${ }^{8}$ and interleukin-6 (IL-6). ${ }^{9}$

In addition to these growth-promoting and activating cytokines, keratinocytes also synthesize T-cell inhibitory cytokines and factors. These include epidermal cell-derived lymphocyte differentiation inhibiting factor, ${ }^{10}$ keratinocyte lymphocyte inhibitory factor, ${ }^{11,12}$ eicosanoids, ${ }^{13-15}$ IL-1 inhibitor, ${ }^{16}$ and transforming growth factor beta. ${ }^{17}$ As well as T-cell stimulatory and inhibitory factors, keratinocytes also elaborate mono- 
nuclear cell chemotactic factors, which are not well characterized. ${ }^{18}$ The actions of some of these epidermal factors and cytokines as they may relate to contact dermatitis are introduced briefly below.

Since its discovery, interleukin-1 has been widely investigated. Epidermal IL-1 release can be induced by specific stimuli, (eg, antigen ${ }^{19}$ ) or by traumatic epidermal injury, (eg, irritant and/or ultraviolet [UV] irradiation ${ }^{19-21}$ ). Interleukin-1 can enhance an immune response directly by inducing $\mathrm{T}$-cell activation and proliferation, ${ }^{22}$ and indirectly by inducing the secretion of GM-CSF. ${ }^{23}$ Interleukin-6 acts synergistically with IL-1 in T-cell activation, and its release may thereby enhance IL-1-induced T-cell proliferation and lymphokine release. ${ }^{9}$

In contrast to the growth stimulatory cytokines, both ELDIF and KLIF inhibit T-cell proliferation and IL-2 production. ${ }^{10-12}$ Keratinocyte lymphocyte inhibitory factor may be a composite of different cytokines, including TGF-beta, since KLIF's inhibitory effect is partially reversible by an antibody against TGFbeta. ${ }^{17,24}$ Eicosanoids, including $\mathrm{PGE}_{2}$, modulate the interaction between $\mathrm{T}$ cells and antigen-presenting cells such that suppressor/effector $\mathrm{T}$ cells are preferentially activated. ${ }^{13}$ Eicosanoids can also function as chemotactic factors for $\mathrm{T}$ cells. Keratinocytes also elaborate factors distinct from eicosanoids, IL-1, and IL-8 that are chemotactic for T cells. ${ }^{18}$ Whether these play a role in contact dermatitis remains to be elucidated.

Another immunocompetent epidermal cell type is the dendritic bone marrow-derived Langerhans cell, which comprises $2 \%$ to $5 \%$ of the total epidermal cell population. ${ }^{25}$ While they represent only a minority of the epidermal cell population, they are the only constitutively present antigen-presenting cell type of the human epidermis. ${ }^{26,27}$ Suprabasally localized in the epidermis, it was the first resident epidermal cell type with immune function to be described. Ultrastructurally, Langerhans cells are distinguished from other cell types by their intracytoplasmic Birbeck's granules. They express CD1, a major histocompatibility complex (MHC) class I-like molecule and human leukocyte antigen (HLA)-DR, an MHC class II molecule. ${ }^{28-30}$ CD1 may be involved in receptor-mediated endocytosis, while HLA-DR is probably involved in presentation of the processed antigen to $\mathrm{CD}^{+} \mathrm{T}$ cells.

\section{Dermal Immunocompetent Cells}

Fibroblasts, endothelial cells, dermal antigen-presenting cells, mast cells, and lymphocytes are the immunocompetent cell types of the dermis.

Structurally, the dermis consists of a framework of collagen, elastic, and reticular fibers embedded in a matrix of glycosaminoglycans. These elements are all produced by the fibroblast. In addition, fibroblasts can be stimulated by IL-1 to produce prostaglandins, which may be involved in inflammation. ${ }^{31}$ Thus, besides producing the dermal framework, fibroblasts also may function in immune reactions.

The dermal vessels are lined by endothelial cells that constitutively express intercellular adhesion molecule-1 (ICAM-1). ${ }^{32}$ This molecule is a natural ligand for lymphocyte function-associated antigen-1 (LFA-1), ${ }^{33}$ a glycoprotein expressed on the surface of most leukocytes. Thus, a molecule expressed by endothelial cells is the natural binding site for a molecule expressed by many leukocytes. These adhesion molecules are recognized to be important for cell-cell interactions; upregulation of their expression by cytokines may be involved in the migration of leukocytes from the vessels into the dermis and the epidermis.

Possible antigen-presenting cells of the dermis are the dermal dendrocytes. They are HLA-DR ${ }^{+}$and are localized around the papillary vascular plexus. These cells may be analogous to dermal $\mathrm{Ia}^{+}$cells of the murine system, which have the capacity to present antigens to T lymphocytes. ${ }^{34}$

Another dermal cell type, the mast cell, can be stimulated by the immune system to release histamine and platelet-activating factor. ${ }^{35,36}$ Histamine generates prostaglandins, stimulates suppressor lymphocytes, and is a potent vasoconstrictor. ${ }^{37,38}$ Platelet-activating factor is a potent stimulus for leukocyte migration and the production of lipoxygenase products of arachidonic acid metabolism. ${ }^{39}$ These products are potent mediators of inflammation.

The few lymphocytes present in the dermis are mainly $T$ cells and include virtually no B cells. These cells are found around the postcapillary venules of the papillary vascular plexus and most of them express HLA-DR and IL-2 receptors, which indicates that they are in a functionally activated state. $T$ cells can be divided into two functionally distinct subsets distinguished by their expression of the CD4 or the CD8 molecule. $\mathrm{CD}^{+} \mathrm{T}$ cells interact with $\mathrm{MHC}$ class IIbearing cells (antigen-presenting cells), while $\mathrm{CD} 8^{+} \mathrm{T}$ cells interact with MHC class I-bearing cells (all nucleated cells). $\mathrm{CD}^{+} \mathrm{T}$ cells can be further divided into helper/inducers, which express high levels of 4B4, and suppressor/inducers, which express high levels of $2 \mathrm{H} 4$. In normal dermis, the $\mathrm{CD}^{+}$and $\mathrm{CD} 8^{+} \mathrm{T}$-cell subsets are evenly distributed. ${ }^{40}$ However, of the $\mathrm{CD} 4^{+} \mathrm{T}$ cells, the majority are $4 \mathrm{~B} 4^{+}$(helper/inducer $\mathrm{T}$ lymphocytes), and the minority are $2 \mathrm{H}^{+}$(suppressor/inducer T lymphocytes). ${ }^{40}$ In contrast, the $\mathrm{CD}^{+} 2 \mathrm{H}^{+}$and the $\mathrm{CD}^{+} 4 \mathrm{~B} 4^{+}$lymphocyte subpopulations in peripheral blood are the same size. 
Activated $\mathrm{T}$ lymphocytes elaborate a variety of lymphokines potentially important for contact dermatitis reactions, including IL- $2,{ }^{41}$ gamma interferon, ${ }^{42}$ IL-3, ${ }^{43,44}$ IL-4, ${ }^{45}$ and GM-CSF. ${ }^{46,47}$ As stated previously, $\mathrm{T}$ lymphocytes can be activated through both antigen-dependent and -independent pathways. Antigen-dependent T-cell activation is critical to the initiation of allergic contact hypersensitivity reactions and is described below.

\section{Pathogenic Mechanism of Allergic Contact Dermatitis}

Most allergens are low molecular weight, highly reactive, lipid-soluble haptens that must be conjugated to an epidermal carrier protein before they can function as complete antigens. Antigen-specific activation of T cells is critically dependent on antigen-presenting cells, which express MHC class II molecules such as HLADR or HLA-DQ. Langerhans cells, which express CD1 and HLA-DR (ie, $\mathrm{CD}^{+} \mathrm{DR}^{+}$), are the only cells in normal human epidermis capable of presenting antigens to $\mathrm{T}$ cells. $\mathrm{CD} 1^{+} \mathrm{DR}^{+}$Langerhans cells can process and present hapten/carrier conjugates into an immunogenic form recognizable by $\mathrm{CD}^{+}$inducer $\mathrm{T}$ lymphocytes. ${ }^{26,27,48}$

It is thought that Langerhans cells internalize antigen by pinocytosis. The pinocytotic antigen-containing vesicle then fuses with a lysosome, creating a phagolysosome. Enzymes within the phagolysosome partly digest the antigen into immunogenic antigen fragments, termed processed antigen. It seems that these combine with cytoplasmic HLA-DR molecules and are transported to the cell surface membrane, where they are coexpressed (Fig. 1). $\mathrm{CD}^{+} \mathrm{T}$ cells cannot recognize antigen alone; only when presented in the context of MHC class II molecules is the antigen recognized.

The T-cell structure responsible for antigen recognition is termed the T-cell receptor and consists of an alpha/beta peptide heterodimer that is rearranged during thymic development. Rearrangement generates a unique antigen-specific receptor for each T-cell clone. The signal produced in response to antigen recognition by the T-cell receptor is transmitted to the interior of the cell via the transduction peptide $\mathrm{CD} 3$, which is complexed with the $\mathrm{T}$-cell receptor. The resulting activation of the $T$ cell causes the $\mathrm{T}$ cell to express IL-2 receptor on its surface and to release IL-2 and other lymphokines. Binding of IL-2 to the IL-2 receptor induces T-cell proliferation. Thus, IL-2 functions as an autocrine T-cell growth factor. Such activation results in the generation of effector $T$ cells capable of mediating delayed-type hypersensitivity reactions ${ }^{49-51}$ as well

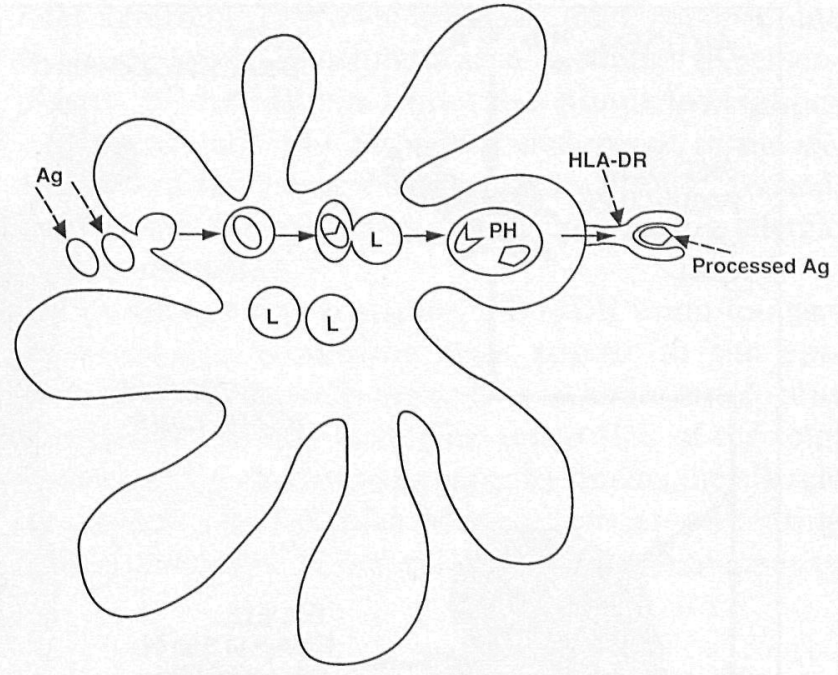

Figure 1. Antigen processing and presentation. Soluble antigens $(\mathrm{Ag})$ are taken up by the Langerhans cell by pinocytosis. The internalized antigen contained within the pinocytotic vesicle is fused with a lysosome (L), creating a phagolysosome (PH). Enzymes within the phagolysosome partially digest the antigen, which is subsequently expressed on the surface of the cell membrane in the context of class II MHC molecules such as HLA-DR. The antigen/HLA-DR complex will now be recognized by the T-cell receptor eliciting T-cell activation.

as the generation of cytotoxic $\mathrm{T}$ cells directed against haptenized epidermal cells. ${ }^{52,53}$ However, immunoregulatory suppressor $\mathrm{T}$ cells that down-modulate the effector responses are also induced..$^{54,55}$ The net effect of the immune response is therefore dependent on the balance between effector and regulatory cells.

Except when very potent allergens are involved, the primary sensitizing event does not normally result in clinical skin lesions. This is probably due to the low number of responder $\mathrm{T}$ lymphocytes present. However, subsequent rechallenges resulting in clonal $\mathrm{T}$-cell expansion and representation of the antigen to primed (memory) $\mathrm{T}$ cells may result in cytokine release and cytotoxicity, generating an acute contact dermatitis lesion. The sensitization and elicitation phases of the immune response in allergic contact dermatitis are described in more detail below.

\section{Sensitization in Allergic Contact Dermatitis}

Following sensitization in animals, Langerhans cells have been found in the dermal lymphatics and in the draining regional lymph nodes. ${ }^{56}$ This may indicate that Langerhans cells take up antigen in the skin and migrate to the paracortical area of the regional lymph node, where they present the processed antigen to unprimed $T$ cells with specificity for that particular antigen. ${ }^{57}$ This results in the generation and expansion of antigen-specific memory $\mathrm{T}$ cells (ie, primed $\mathrm{T}$ cells), 


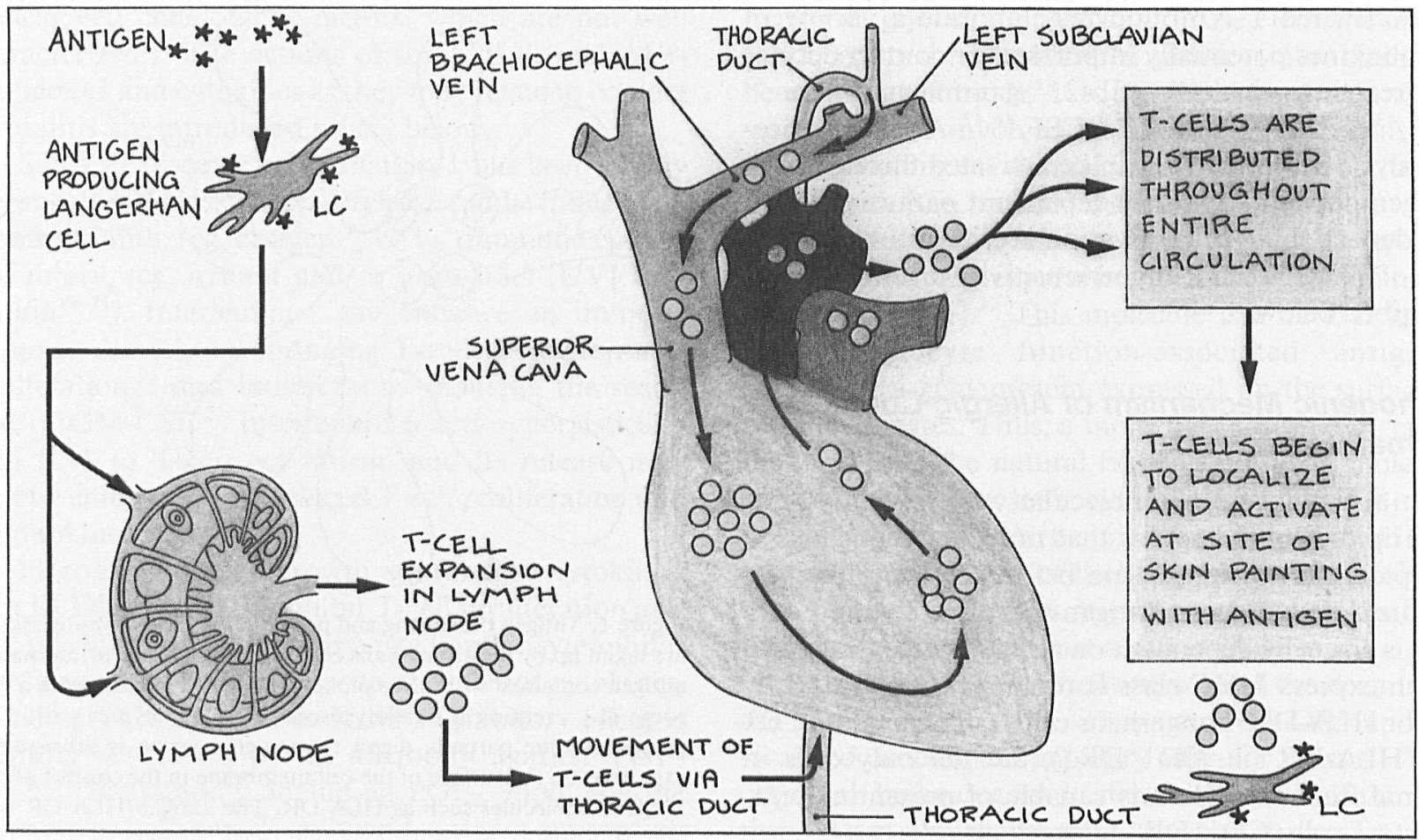

Figure 2. Sensitization, the afferent phase of the immune response in allergic contact dermatitis. Lipid soluble reactive haptens applied to the skin cross the stratum corneum and bind to protein carriers in the skin creating complete antigens. The antigen (hapten-carrier conjugate) is internalized by the Langerhans cell, processed, and then expressed on the surface membrane in the context of class II MHC molecules. The Langerhans cell moves out of the epidermis through the afferent draining lymphatic to the regional lymph nodes. Following Langerhans cell antigen presentation to unprimed $\mathrm{T}$ cells in the paracortical area, the $\mathrm{T}$ cells undergo expansion then exit the node. The primed (memory) $\mathrm{T}$ cells travel via the thoracic duct to the superior vena cava, are distributed through the circulatory system, and home to the site challenged by hapten. Representation of antigens to primed (memory) $\mathrm{T}$ cells can now occur and will result in amplification of the immune response. (Reproduced with permission from Cooper K, Roitt IM, Du Vivier A, et al. Immunology Slide Atlas. New York: Gower Medical Publishing, 1989.)

which then distribute throughout the circulation and home to the site of antigen challenge (Fig. 2).

The Langerhans cell's role in the induction of contact hypersensitivity is highlighted by studies performed in Langerhans cell-depleted skin, such as murine tail skin, UV-irradiated skin, or in epidermal cell suspensions depleted of Langerhans cells by UV irradiation. Sensitization in these systems results in the development of antigen-specific tolerance. ${ }^{58-60}$ Peroral or intravenous administration of the allergen may also result in antigen-specific tolerance. Thus, it appears that when antigen is presented by non-Langerhans antigen-presenting cells, $\mathrm{T}$ suppressor lymphocytes are activated, and tolerance, rather than contact hypersensitivity, results.

\section{Elicitation of Allergic Contact Dermatitis}

Rechallenge of the skin will result in representation of the antigen by Langerhans and possibly non-Langer- hans antigen-presenting cells to primed $\mathrm{T}$ cells. This may take place in the epidermis, the dermis, or in the regional draining lymph nodes, and results in T-cell activation. As stated previously, these activated $T$ cells release a variety of lymphokines, such as IL- $2,{ }^{41}$ gamma-interferon, ${ }^{42}$ GM-CSF, ${ }^{46,47}$ IL- $3,{ }^{43,44}$ and IL-4. ${ }^{45}$ These lymphokines have a variety of immunologic effects that are potentially important in contact dermatitis.

Gamma-interferon released from lesional activated $\mathrm{T}$ cells upregulates the expression of intercellular adhesion molecules, such as ICAM-1, on both keratinocytes and endothelial cells. ${ }^{24,61,62}$ This is thought to be important for the recruitment of cells that express LFA-1, such as T cells and other leukocytes,${ }^{33}$ which then participate in the ongoing immune response.

Interleukin-3 is present in the early phases of a delayed-type hypersensitivity reaction ${ }^{63}$ and is released from activated $T$ cells. It induces mast cell proliferation and is involved in the activation of monocytes. 
Mast cells and monocytes are present in increased numbers in contact hypersensitivity reactions. Furthermore, IL-3 and GM-CSF, as well as other lymphokines, may enhance keratinocyte proliferation. ${ }^{64}$ Thus, these activated T-cell products may be partially responsible for the epidermal hyperplasia seen in contact dermatitis (Fig. 3).

In addition to lymphokines released by activated $\mathrm{T}$ cells, other cytokines are important in the elicitation of contact dermatitis. Interleukin-1, a cytokine released from Langerhans cells, macrophages, and keratinocytes has been found in increased amounts in the epidermis during an allergic patch test reaction. ${ }^{19}$ The binding of IL-1 to keratinocyte IL-1 receptors stimu- lates keratinocyte growth and may thereby contribute to the epidermal hyperplasia seen in contact hypersensitivity. ${ }^{22,23}$ Interleukin-1 may also stimulate keratinocyte release of GM-CSF, which may result in the expansion of the Langerhans cell population. ${ }^{23}$ Indeed, the number of Langerhans cells is increased in allergic contact dermatitis. ${ }^{65-68}$

In allergic skin reactions, $\mathrm{CD}^{-} \mathrm{DR}^{+}$non-Langerhans antigen-presenting cells appear in the epidermis. ${ }^{65,68}$ These cells are able to activate autologous $\mathrm{T}$ cells and are responsible for up to $50 \%$ of the total epidermal T-cell activating capacity during the allergic reaction. ${ }^{68}$ The function of these antigen-presenting cells is unknown. However, they may be analogous to

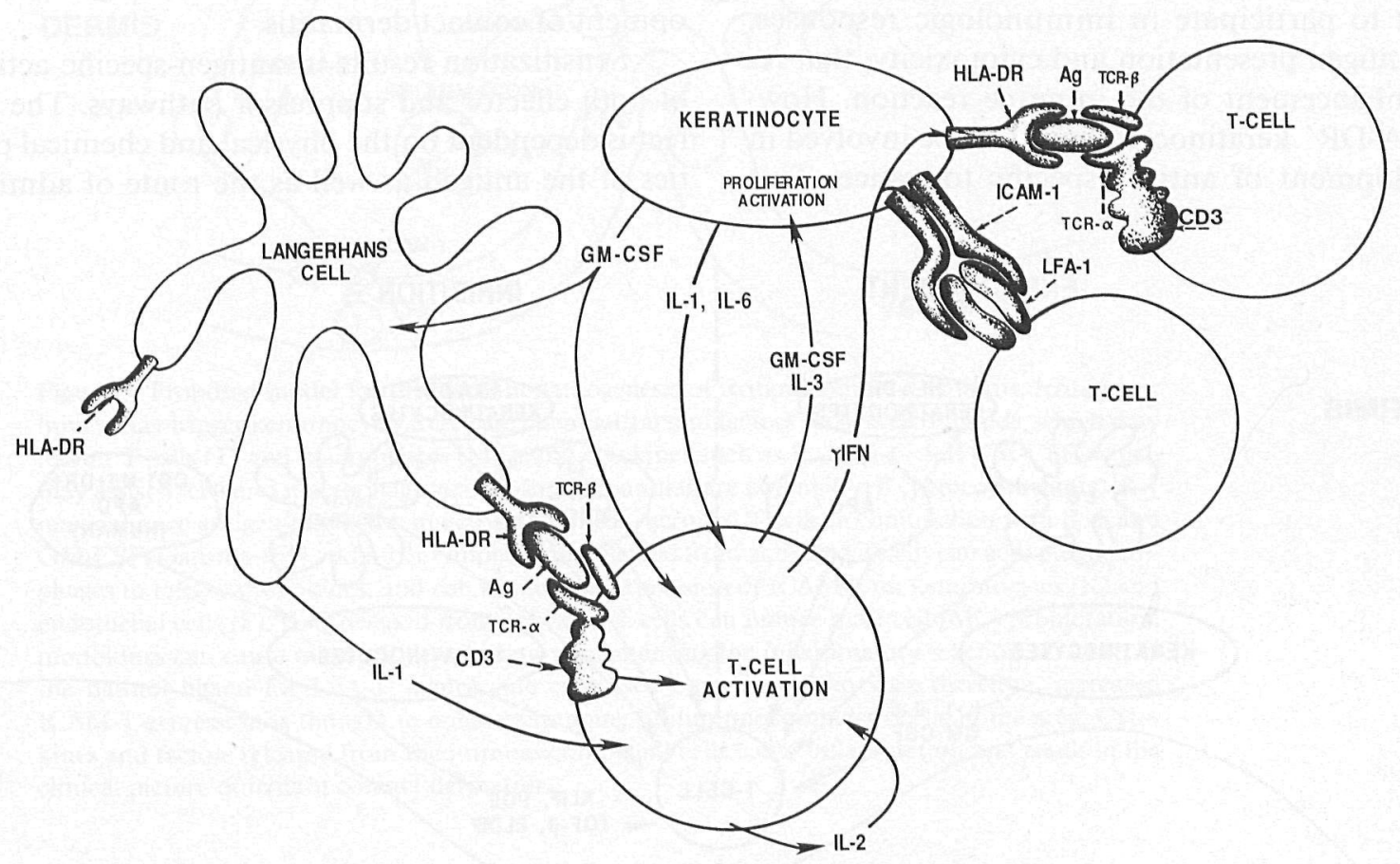

Figure 3. Elicitation, the efferent phase of the immune response in allergic contact dermatitis. Presentation of antigen in the skin by Langerhans and other antigen-presenting cells to primed (memory) $\mathrm{T}$ cells results in $\mathrm{T}$-cell activation and expansion and lymphokine release. The antigen is presented in the context of HLA-DR class II MHC molecules to the T-cell receptor, a heterodimer composed of an alpha and beta peptide chain. The signal is transmitted from the T-cell receptor to the interior of the cell via a transduction peptide termed CD3. Activation causes the $\mathrm{T}$ cells to release lymphokines including IL-2, IL-3, gamma-IFN and GM-CSF and to express IL-2 receptors. IL-2 binding to the IL-2 receptor induces T-cell proliferation. IL-3 and GM-CSF may induce keratinocyte proliferation and may be responsible for the epidermal hyperplasia seen in contact dermatitis. Gamma-IFN and tumor necrosis factor induce keratinocyte expression of intercellular adhesion molecules (e.g., ICAM-1), whereas only gamma-interferon induces HLA-DR. ICAM-1 is the natural ligand for LFA-1, a molecule expressed by many leukocytes that is important for cell-cell interaction. ICAM-1 also may be responsible for compartmentalization of leukocytes in the skin during a contact dermatitis reaction. Keratinocytes that express HLA-DR may, under certain circumstances, present protease-digested antigen fragments to already primed $\mathrm{T}$ cells, thereby enhancing the ongoing immune response. HLA-DR ${ }^{+}$keratinocytes also may be a target for certain cytotoxic effector T cells. Cytokines such as IL-1, IL-6, and GM-CSF released from activated keratinocytes can stimulate activation and proliferation of $\mathrm{T}$ cells and, in the case of GMCSF, Langerhans cells. Monocytes and mast cells also may be activated and may release proinflammatory mediators. Spongiosis, cell injury, and cell death are the combined effect of these interactions, and the clinical picture of allergic contact dermatitis results. 
UV-induced non-Langerhans cells, which downregulate immune responses. Non-Langerhans antigen-presenting cells may function as a negative feedback mechanism downregulating the hypersensitivity reaction. This hypothesis currently is under investigation.

Keratinocytes in allergic and irritant skin reactions express both ICAM-1 and HLA-DR. These immunocompetent surface molecules are probably induced by lymphokines such as gamma-interferon released from local $\mathrm{T}$ cells. ${ }^{24,61,62,69-71}$ HLA-DR ${ }^{+}$keratinocytes are, under certain circumstances, able to present antigenic peptide fragments to primed (memory) $\mathrm{T}$ cells. ${ }^{72} \mathrm{Ad}$ ditionally, HLA-DR ${ }^{+}$keratinocytes can also act as targets for MHC class II restricted cytotoxic T-cell clones. ${ }^{72}$ Thus, HLA-DR expression may allow keratinocytes to participate in immunologic responses, such as antigen presentation and cytotoxicity, that result in enhancement of the immune reaction. However, HLA-DR ${ }^{+}$keratinocytes may also be involved in the development of antigen-specific tolerance. This aspect of HLA-DR ${ }^{+}$keratinocytes is discussed in an upcoming section.

\section{Regulation of the Inflammatory Response in Allergic Contact Dermatitis}

Multiple cell types, factors, and cytokines are involved in regulation of the inflammatory response in allergic contact dermatitis. Inhibitory and stimulatory factors interact to determine whether the immune response is up- or downregulated (Fig. 4). Normally, stimulatory signals provided by Langerhans cells are counteracted by inhibitory signals provided by keratinocytes such that an immune response is not initiated. Antigens or irritants can upset this balance, resulting in the development of contact dermatitis.

Sensitization results in antigen-specific activation of both effector and suppressor pathways. The net effect is dependent on the physical and chemical properties of the antigen as well as the route of administra-

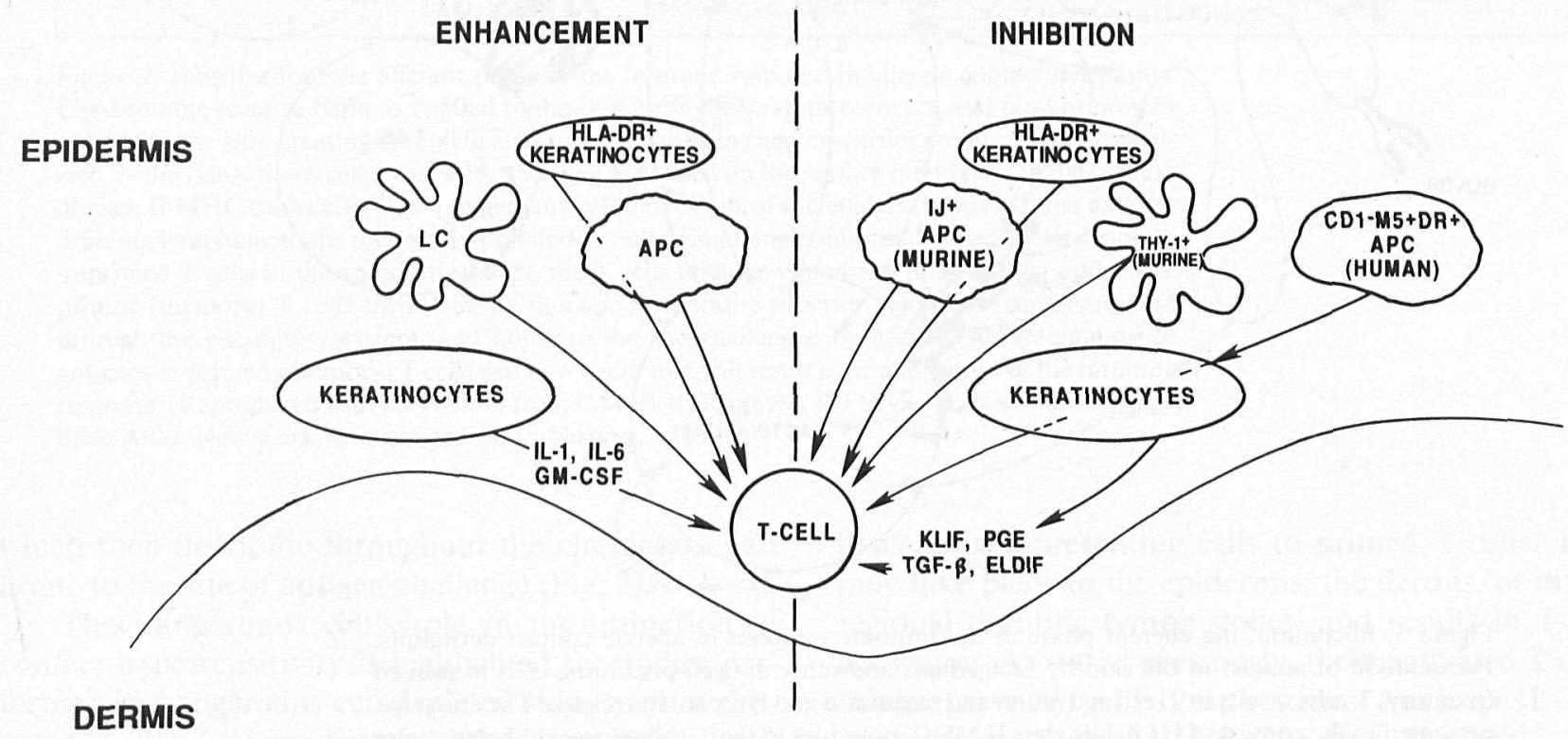

Figure 4. Mechanisms involved in epidermal immune response regulation. Multiple factors and mechanisms are responsible for immune regulation in the skin. Langerhans cells (LC) provide positive signals for T-cell activation; other nonresident antigen-presenting cells present in inflammed skin may enhance this signal. Keratinocytes capable of releasing T-cell stimulatory cytokines such as IL-1, IL-6, and GM-CSF also may function to enhance the immune response. Although the alloantigen-presenting capacity of HLA-DR ${ }^{+}$keratinocytes is weak, the keratinocytes can, under certain circumstances, present antigens leading to T-cell activation and possibly also lymphokine release, and thus potentiate an ongoing immune response. On the other hand, the epidermis also contains the capacity to downregulate the immune response. UV-induced nonLangerhans $\mathrm{CDI}^{-} \mathrm{OKM} 5^{+} \mathrm{DR}^{+}$antigen-presenting cells seem to preferentially activate suppressor pathways. Furthermore, HLA-DR ${ }^{+}$keratinocytes can present antigen to unprimed T cells, resulting in antigen-specific tolerance to subsequent antigen presentation by Langerhans cells. A variety of T-cell inhibitory cytokines may be released from keratinocytes in vitro including KLIF, PGE 2 , TGF-beta, and ELDIF. The mechanism responsible for regulation of the release of stimulatory and inhibitory cytokines from the keratinocytes is unknown. In the murine system, $\mathrm{IJ}^{+}$antigen-presenting cells (APC) and Thy $\mathrm{I}^{+}$dendritic T cells also contain the capability to downregulate immune responses. Clear human analogues to the two murine cell types, however, await identification. 


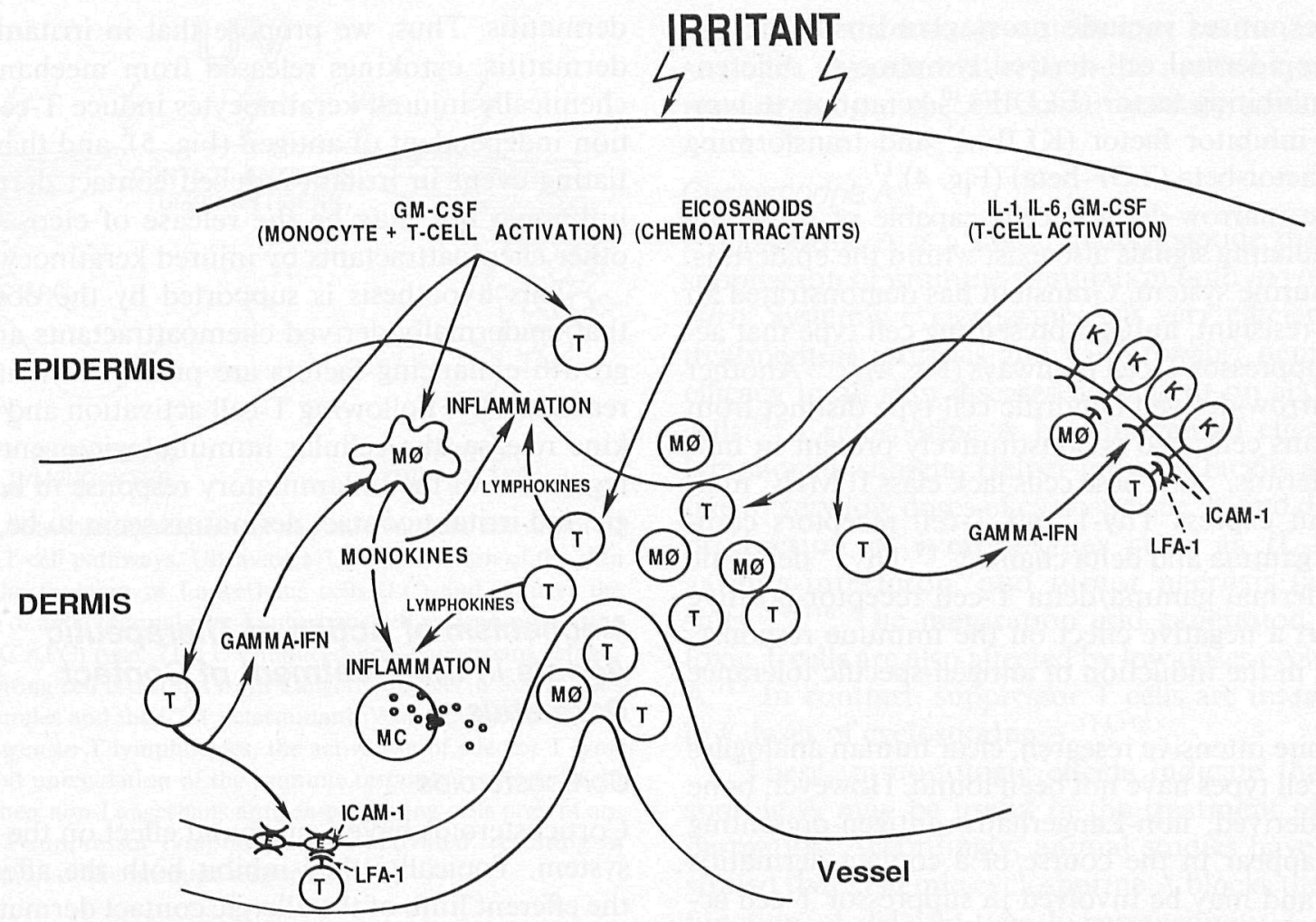

Figure 5. Proposed model for the immunopathogenesis of irritant contact dermatitis. Irritants or injury may trigger keratinocytes to release chemoattractant factors such as eicosanoids, which may recruit T cells (T) and macrophages (M $\phi)$, and cytokines such as IL-1, IL-6, and GM-CSF, which may assist T-cell and macrophage activation. Eicosanoids are potent T-cell chemoattractants. IL-1 may enhance antigen-independent activation of the recruited T cells in conjunction with IL- 6 and GM-CSF. Gamma-IFN and other lymphokines released from activated T cells can activate macrophages to release monokines, and can induce the expression of ICAM-1 on keratinocytes $(\mathrm{K})$ and endothelial cells (E). IL-3 released from activated T cells can induce mast cell (MC) proliferation; monokines can cause mast cell degranulation augmenting the inflammatory reaction. ICAM-1 is the natural ligand for LFA-1, a molecule expressed on many leukocytes; therefore, increased ICAM-1 expression is thought to enhance trapping of immunocompetent cells in the area. Cytokines and factors released from the immunocompetent cells cause inflammation and result in the clinical picture of irritant contact dermatitis.

tion. High concentrations of antigen induce antigenspecific unresponsiveness through activation of antigen-specific suppression. This suppression is transferrable through donor $\mathrm{T}$ lymphocytes to syngeneic recipients. ${ }^{73}$ Activation of antigen-specific suppressor $\mathrm{T}$ cells in this system may be due to systemic antigen absorption following overloading of the skin by antigen, thus bypassing epidermal Langerhans cells. As mentioned earlier, antigen administration that bypasses the Langerhans cells results in the activation of antigen-specific suppressor $T$ cells, which can downregulate the immune response..$^{60,74,75}$ This mechanism also may be responsible for the relative rarity of contact dermatitis in workers exposed to large allergen doses, such as nickel workers. It has also been used by Kligman and others to treat patients with poison ivy dermatitis with oral urushiol extract. ${ }^{76}$ However, urushiol extract desensitization is short-lived and the side effects are troublesome.
The type of antigen is also important in sensitization. For example, application to the skin of 2,4-dinitrothiocyanatebenzene (DNTB), an antigen that crossreacts with 2,4-dinitrofluorobenzene (DNFB), results in suppressor T-cell activation that downregulates subsequent reactions to $\mathrm{DNFB}{ }^{77,78}$

As mentioned earlier, cytokines released from activated $\mathrm{T}$ cells induce keratinocyte HLA-DR expression, which may allow them to enhance the immune reaction. Presentation of antigen by $\mathrm{HLA}_{-} \mathrm{DR}^{+}$keratinocytes to unprimed T cells, however, results in the development of antigen-specific unresponsiveness to later antigen presentation by Langerhans cells. Thus, HLA-DR $^{+}$keratinocytes also may downregulate the inflammatory response (Fig. 4). ${ }^{79}$

Cytokines derived from keratinocytes can exert inhibitory or stimulatory effects on $\mathrm{T}$ cells, and their balance may be a critical factor determining T-cell activation state. Keratinocyte factors that downregulate 
T-cell responses include prostaglandins,${ }^{80}$ eicosanoids, ${ }^{13}$ epidermal cell-derived lymphocyte differentiation inhibiting factor (ELDIF) ${ }^{10}$ keratinocyte lymphocyte inhibitor factor (KLIF), ${ }^{12}$ and transforming growth factor-beta (TGF-beta) (Fig. 4). ${ }^{17}$

Bone marrow-derived cells capable of providing downregulating signals also exist within the epidermis. In the murine system, Granstein has demonstrated an $\mathrm{IJ}^{+}$, UV-resistant, antigen-presenting cell type that activates suppressor T-cell pathways (Fig. 4) ${ }^{81,82}$ Another bone marrow-derived dendritic cell type distinct from Langerhans cells also is constitutively present in murine epidermis. ${ }^{83-86}$ These cells lack class II MHC molecules but express Thy-1 and T-cell receptors composed of gamma and delta chains. ${ }^{87-89}$ Thy $1^{+}$dendritic intraepidermal gamma/delta $\mathrm{T}$-cell receptor-positive cells exert a negative effect on the immune response, resulting in the induction of antigen-specific tolerance (Fig. 4). ${ }^{90}$

Despite intensive research, clear human analogues to these cell types have not been found. However, bone marrow-derived, non-Langerhans, antigen-presenting cells do appear in the course of a contact dermatitis reaction and may be involved in suppressor T-cell activation. ${ }^{65,68}$ This hypothesis is supported by the observation that these non-Langerhans cells demonstrate the OKM $1^{-} \mathrm{OKM} 5^{+}$phenotype. ${ }^{68}$ This phenotype is analogous to a minor $(<5 \%)$ subset of blood monocytes uniquely capable of activating autoreactive immunoregulatory $\mathrm{T}$ cells capable of immune downregulation. $^{91-93}$

\section{Pathogenic Mechanism of Irritant Contact Dermatitis}

Allergic and irritant dermatitis share many clinical and histopathologic features and are often difficult to distinguish; however, clear differences exist. For example, although both responses are characterized by a similar distribution of T-cell subsets, the number of $\mathrm{CD} 1^{+}$ Langerhans cells is decreased in irritant reactions, whereas it is increased in allergic reactions. ${ }^{65,66,68,94}$ These findings are highlighted by our observation of decreased epidermal antigen-presenting cell capacity to activate $T$ cells following irritant challenge and increased epidermal antigen-presenting cell function following allergic challenge. ${ }^{65,68}$

While allergic contact dermatitis is a classic example of antigen-dependent T-cell activation, the pathogenic mechanism of irritant contact dermatitis is not known. We think, however, that the decreased capacity of irritant-challenged epidermis to activate $T$ cells suggests that antigen-dependent pathways are not critical for the immunologic response in irritant contact dermatitis. Thus, we propose that in irritant contact dermatitis, cytokines released from mechanically or chemically injured keratinocytes induce T-cell activation independent of antigen (Fig. 5), and that the initiating event in irritant-induced contact dermatitis is unknown but may be the release of eicosanoids or other chemoattractants by injured keratinocytes.

This hypothesis is supported by the observation that epidermally derived chemoattractants and T-cell growth enhancing factors are present in irritant skin reactions. ${ }^{19,20}$ Following T-cell activation and lymphokine release, the cellular immunologic event and the regulation of the inflammatory response in both allergic and irritant contact dermatitis seem to be similar.

\section{Mechanism of Action of Therapeutic Agents in the Treatment of Contact Dermatitis}

\section{Corticosteroids}

Corticosteroids have a profound effect on the immune system. Topically, they inhibit both the afferent and the efferent limb of the allergic contact dermatitis reaction. ${ }^{95,96}$ Steroids inhibit antigen-specific lymphocyte activation and proliferation. ${ }^{97}$ This is probably due to direct effect on both antigen-presenting cells and $\mathrm{T}$ cells. Topical application of steroids to the skin depletes Langerhans cells of CDI and HLA-DR molecules, abrogating their antigen-presenting function. ${ }^{98-100}$ Corticosteroids also block T-cell release of IL-2, thereby inhibiting T-cell proliferation. ${ }^{97}$ These immunomodulatory effects turn off the ongoing immune response in contact dermatitis and are responsible for the therapeutic effects of corticosteroids in the treatment of contact dermatitis.

\section{Ultraviolet Radiation}

Ultraviolet light also exerts its therapeutic effects on contact dermatitis through the immune system. Ultraviolet exposure of the skin abrogates Langerhans cell function and induces the appearance of bone marrowderived antigen-presenting cells, which can activate $T$ suppressor cells.

Ultraviolet exposure of the skin results in the disappearance of Langerhans cell surface molecules (CD1 and HLA-DR), and thus eliminates their antigen-presenting function (Fig. 6). ${ }^{101,102}$ However, HLA-DR ${ }^{+}$, bone marrow-derived, antigen-presenting melanophages appear in the epidermis in response to the irradiation. ${ }^{103-106}$ These non-Langerhans antigen-presenting cells (non-LC APC) are ultrastructurally distinct from Langerhans cells in that they lack Birbeck's granules and express melanosomes within phagolysosomes. 


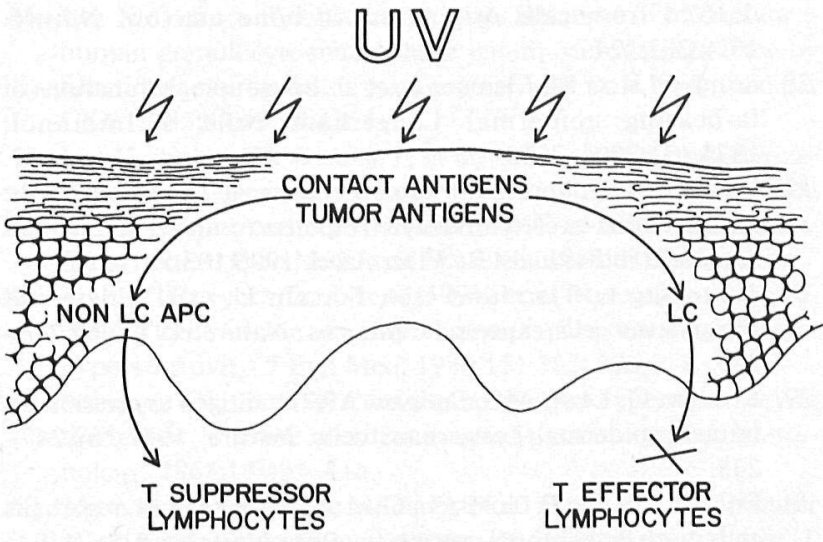

Figure 6. Ultraviolet irradiation of the skin induces activation of suppressor T-cell pathways. Ultraviolet (UV) irradiation of the skin abrogates the function of Langerhans cells (LC) and induces the appearance of an epidermal non-Langerhans cell antigen-presenting cell (non-LC APC) type. This UV-induced non-Langerhans cell antigen-presenting cell is distinct from Langerhans cells in that it lacks Birbeck granules and the CD1 determinant. When Langerhans cells present antigen to $\mathrm{T}$ lymphocytes, the activation of effector $\mathrm{T}$ lymphocytes and upregulation of the immune response is the result. In contrast, when non-Langerhans antigen-presenting cells present antigen, the $\mathrm{T}$-suppressor lymphocytes are activated, resulting in downregulation of the immune response.

Phenotypically, they lack the CD1 determinant expressed on epidermal Langerhans cells and bear the $\mathrm{OKM} 1^{-} \mathrm{OKM} 5^{+}$phenotype, demonstrating analogy to a minor subpopulation of antigen-presenting cells in the blood ${ }^{91}$ that can activate immunoregulatory $\mathrm{T}$ cells. $^{93}$ These non-LC APC are capable of activating both antigen-specific $\mathrm{CD}^{+} 2 \mathrm{H} 4^{-} \mathrm{T}$ cells, which provide help for B-cell immunoglobulin production, as well as autoreactive $\mathrm{CD}^{+} 2 \mathrm{H} 4^{+} \mathrm{T}$ cells, which induce the maturation of suppressor $\mathrm{T}$ cells. ${ }^{107,108}$ However, $\mathrm{CD} 4{ }^{+} 2 \mathrm{H}^{+}{ }^{+}$suppressor/inducer T-cell activation dominates, and the net functional effect is therefore the induction of suppression (Fig. 6). ${ }^{109,110}$

In the murine system, sensitization through skin previously exposed to low doses of UV radiation results in antigen-specific unresponsiveness. This local effect is due to the appearance of antigen specific $T$ suppressor cells that operate at the afferent limb of the immune response to prevent the activation of effector cells for delayed-type hypersensitivity. ${ }^{111}$ High doses of UV radiation, however, result in systemic suppression of the immune response, where sensitization through either exposed or unexposed skin results in induction of antigen-specific tolerance..$^{59,112}$ Although the cellular mechanisms responsible for induction of these suppressor T cells are not clear, UV-resistant, IJ-restricted, antigen-presenting cells or Thy $1^{+}$dendritic epidermal cells that express gamma-delta T-cell receptors may be important. $^{81,82,90}$ Ultraviolet-induced epidermal $\mathrm{CD}^{-}{ }^{-} \mathrm{OKM} 5^{+} \mathrm{DR}^{+}$, non-Langerhans, antigen-present- ing cells of the human system may be the functional analogue to epidermal cells in the murine system that provide antigen-specific downregulating signals.

\section{Cyclosporine A}

Cyclosporine $\mathrm{A}$ is a cyclic undecapeptide that causes suppression of immune stimulation both in vivo and in vitro. Systemic cyclosporine A is very efficient in the treatment of psoriasis and will probably demonstrate efficacy in all skin diseases dependent on activated $\mathrm{T}$ cells. ${ }^{113}$ Cyclosporine $\mathrm{A}$ has differential effects on $\mathrm{T}$ lymphocyte subsets. Helper-inducer T cells are sensitive to very low doses of cyclosporine $\mathrm{A}$, and decreased production of lymphokines such as IL-2, IL-4, gamma-interferon, and tumor necrosis factor results. ${ }^{114-116}$ The maturation and generation of cytotoxic $T$ cells are also affected by low doses cyclosporine A. ${ }^{117}$ In contrast, suppressor $\mathrm{T}$ cells are insensitive to low doses of cyclosporine A. ${ }^{114,118}$

These immunologic effects indicate that cyclosporine A may be useful in the treatment of contact dermatitis. Accordingly, animal studies have demonstrated that systemic cyclosporine A blocks the effector function of delayed-type hypersensitivity $\mathrm{T}$ cells, although the priming of these cells is cyclosporine A-insensitive. ${ }^{119}$ Topical cyclosporine $\mathrm{A}$ inhibits the elicitation of contact hypersensitivity in guinea pigs. ${ }^{120} \mathrm{How}-$ ever, application of topical cyclosporine A to human skin has only minimal effect, probably due to either lack of absorption or epidermal/dermal inactivation of the drug. ${ }^{121}$ Systemic cyclosporine A may play a role in the treatment of severe recalcitrant contact dermatitis; however, due to its nephrotoxicity, widespread use of this agent in contact dermatitis awaits an efficient topical formulation.

\section{References}

1. Sauder DN, Carter CS, Katz SI, et al. Epidermal cell production of thymocyte activating factor (ETAF). J Invest Dermatol. 1982;79:34-39.

2. Luger TA, Stadler BM, Katz SI, et al. Epidermal cell (keratinocyte)-derived thymocyte-activating factor (ETAF). J Immunol. 1981;127:1493-1498.

3. Kupper TS, Ballard DW, Chua AO, et al. Human keratinocytes contain mRNA indistinguishable from monocyte interleukin I alpha and beta mRNA. J Exp Med. 1986;164:2095-2100.

4. Cooper KD, Baadsgaard O, Elder JT, et al. Increased levels of an interleukin-1 inhibitor block interleukin-1 activity but not immunoreactivity or mRNA expression of interleukin-1 beta in psoriasis skin (abstract). J Invest Dermatol. 1988;90:552.

5. Luger TA, Wirth U, Kock A. Epidermal cells synthesize a cytokine with interleukin 3-like properties. J Immunol. 1985;134:915-919.

6. Danner M, Luger TA. Human keratinocytes and epidermoid carcinoma cell lines produce a cytokine with interleukin 3-like activity. J Invest Dermatol. 1987;88:353-361. 
7. Chodakewitz JA, Kupper TS, Coleman DL. Keratinocyte-derived granulocyte/macrophage colony-stimulating factor induces DNA synthesis by peritoneal macrophages. J Immunol. 1988;140:832-836.

8. Luger TA, Uchida A, Kock A, et al. Human epidermal cells and squamous carcinoma cells synthesize a cytokine that augments natural killer cell activity. J Immunol. 1985;134:24772483.

9. Kupper TS, May L, Birchall N, et al. Keratinocytes produce interleukin 6 , a cytokine which can provide a 2 nd signal in the activation of T-cells (abstract). Clin Res. 1988;36:665.

10. Nicolas JF, Kaiserlian D, Dardenne M, et al. Epidermal cell derived lymphocyte differentiating factor (ELDIF) inhibits in vitro lymphoproliferative responses and interleukin-2 production. J Invest Dermatol. 1987;88:161-166.

11. Nickoloff BJ, Basham TY, Merigan TC, et al. Cultured keratinocytes secrete a substance which inhibits allogeneic lymphocyte proliferation (abstract). J Invest Dermatol. 1985;84:302.

12. Nickoloff BJ, Basham TY, Torseth J, et al. Human keratinocyte-lymphocyte reactions in vitro. J Invest Dermatol. 1986;87:11-18.

13. Rola-Pleszczynski M. Differential effects of leukotriene B4 on $\mathrm{T} 4+$ and $\mathrm{T} 8+$ lymphocyte phenotype and immunoregulatory functions. J Immunol. 1985;135:1357-1360.

14. Hammerstrom S, Lindgren JA, Marcelo C, et al. Arachidonic acid transformations in normal and psoriatic skin. J Invest Dermatol. 1979;73:180-183.

15. Grabbe J, Czarnetzki BM, Mardin M. Release of lipoxygenase products of arachidonic acid from freshly isolated human keratinocytes. Arch Dermatol Res. 1984;276:128-130.

16. Walsh LJ, Lander PE, Seymour GJ, et al. Isolation and purification of ILS, an interleukin 1 inhibitor produced by human gingival epithelial cells. Clin Exp Immunol. 1987;68:366-374.

17. Nickoloff BJ. Keratinocytes produce a lymphocyte inhibitory factor which is partially reversible by an antibody to transforming growth factor-beta. Ann NY Acad Sci. 1988;548:312-320.

18. Zachariae C, Ternowitz T, Larsen CG, et al. Epidermal lymphocyte chemotactic factor specifically attracts OKT4-positive lymphocytes. Arch Dermatol Res. 1988;280:354-357.

19. Larsen CG, Ternowitz T, Larsen FG, et al. Epidermis and lymphocyte interactions during an allergic patch test reaction: increased activity of ETAF/IL-1, epidermal derived lymphocyte chemotactic factor and mixed skin lymphocyte reactivity in persons with type IV allergy. J Invest Dermatol. 1988;90:230-233.

20. Larsen CG, Ternowitz T, Larsen FG, et al. Epidermal derived lymphokines and their presence in allergic and irritant skin reactions (abstract). J Invest Dermatol. 1988;91:405.

21. Kupper TS, Chua AO, Flood P, et al. Interleukin-1 gene expression in cultured human keratinocytes is augmented by ultraviolet irradiation. J Clin Invest. 1987;80:430-436.

22. Ristow HJ. A major factor contributing to epidermal proliferation in inflammatory skin diseases appears to be interleukin 1 or a related protein. Proc Natl Acad Sci USA. 1987;84:19401944.

23. Kupper TS, Lee F, Birchall N, et al. Interleukin 1 binds to specific receptors on human keratinocytes and induces granulocyte macrophage colony-stimulating factor mRNA and protein: a potential autocrine role of interleukin 1 in epidermis. $\mathrm{J}$ Clin Invest. 1988;82:1787-1792.

24. Nickoloff BJ. Keratinocytes produce a lymphocyte inhibitory factor which is partially reversible by an antibody to transforming growth factor-beta. Ann NY Acad Sci. 1988;548:312320.

25. Katz SI, Tamaki K, Sachs DH. Epidermal Langerhans cells are derived from cells originating in bone marrow. Nature. 1979;282:324.

26. Stingl G, Katz SI, Clement L, et al. Immunologic functions of Ia-bearing epidermal Langerhans cells. J Immunol. 1978;121:2005-2013.

27. Braathen LR. Studies on human epidermal Langerhans cells: III. induction of $\mathrm{T}$ lymphocyte response to nickel sulphate in sensitized individuals. Br J Dermatol. 1980;103:517-526.

28. Klareskog L, Tjernlund UM, Forsum U, et al. Epidermal Langerhans cells express Ia antigens. Nature. 1977;268:248 250.

29. Rowden G, Lewis MG, Sullivan AK. Ia antigen expression on human epidermal Langerhans cells. Nature. 1977;268:247248.

30. Fithian E, Kung P, Goldstein G, et al. Reactivity of Langerhans cells with hybridoma antibody. Proc Natl Acad Sci USA. 1981;78:2541-2544.

31. Raz A, Wyche A, Siegel N, et al. Regulation of fibroblast cyclooxygenase synthesis by interleukin-1. J Biol Chem. 1988;263:3022-3028.

32. Dustin ML, Rothlein R, Bahn AK. Induction by IL-1 and interferon: tissue distribution, biochemistry, and function of a natural adherence molecule (ICAM-1). J Immunol. 1986;137:245-254.

33. Marlin SD, Springer TA. Purified intercellular adhesion molecule-1 (ICAM-1) is a ligand for lymphocyte function-associated antigen-1 (LFA-1). Cell. 1987;51:813-819.

34. Kang S, Duraiswamy N, Crespo J, et al. Phenotype and antigen presenting cell function of murine dermal cells (abstract). Clin Res. 1987;35:819.

35. Camussi G, Aglietta M, Coda R, et al. Release of platelet activating factor and histamine: II. the cellular origin of human PAF: monocytes, polymorphonuclear neutrophils, and basophils. Immunology. 1981;42:191-199.

36. Paterson NAM, Wasserman SI, Said JW, et al. Release of chemical mediators from partially purified human lung mast cells. J Immunol. 1976;117:1356-1362.

37. Alhenc-Gelas F, Tsai SJ, Callahan KS, et al. Stimulation of prostaglandin formation by vasoactive mediators in cultured human endothelial cells. Prostaglandins. 1982;24:723-742.

38. Rocklin RE, Haberek-Davidson A. Histamine activates suppressor cells in vitro using a coculture technique. J Clin Immunol. 1981;117:73-79.

39. Shaw JO, Pinckard RN, Ferrigni KS, et al. Activation of human neutrophils with 1-0-hexadecyl/octadecyl-2-acetyl-snglycerol-3-phosphorylcholine; the active moiety of platelet activating factor. J Immunol. 1981;127:1250-1255.

40. Bos JD, Zonneveld IN, Das PK, et al. The skin immune system (SIS): distribution and immunophenotype of lymphocyte subpopulations in normal human skin. J Invest Dermatol. 1987;88:569-573.

41. Morgan DA, Ruscetti FW, Gallo R. Selective in vitro growth of $\mathrm{T}$ lymphocytes from normal human bone marrows. Science. 1976;193:1007-1008.

42. Herberman RB, Ortaldo JR, Timonen T, et al. Interferon and natural killer (NK) cells. Tex Rep Biol Med. 1981;41:590-595:

43. Suzuki R, Suzuki S, Takahashi T, et al. Production of a cytokine with interleukin 3-like properties and cytokine-dependent proliferation in human autologous mixed lymphocyte reaction. J Exp Med. 1986;164:1682-1699.

44. Suzuki R, Suzuki S, Igarashi M, et al. Induction of interleukin 3 but not interleukin 2 or interferon production in the syngeneic mixed lymphocyte reaction. J Immunol. 1986;137:1564-1572.

45. Paliard X, de Waal MR, Yssel H, et al. Simultaneous production of IL-2, IL-4, and IFN-gamma by activated human CD4+ and CD8 + T cell clones. J Immunol. 1988;141:849-855. 
46. Lee $\mathrm{K}$, Yokota $\mathrm{T}$, Otsuka $\mathrm{T}$, et al. Isolation of cDNA for a human granulocyte-macrophage colony-stimulating factor by functional expression in mammalian cells. Proc Natl Acad Sci USA. 1985;82:4360-4364.

47. Lee $\mathrm{K}$, Yokota $\mathrm{T}$, Otsuka $\mathrm{T}$, et al. Isolation and characterization of a mouse interleukin cDNA clone that expresses B-cell stimulatory factor 1 activities and T-cell and mast cell stimulating activities. Proc Natl Acad Sci USA. 1986;83:2061-2065.

48. Ptak W, Rozycka D, Askenase PW, et al. Role of antigen-presenting cells in the development and persistence of contact hypersensitivity. J Exp Med. 1980;151:362-375.

49. Asherson GL, Ptak W. Contact and delayed hypersensitivity in the mouse: I. active sensitization and passive transfer. Immunology. 1968;15:405-416.

50. Marchal G, Seman M, Milon G, et al. Local adoptive transfer of skin delayed-type hypersensitivity initiated by a single $\mathrm{T}$ lymphocyte. J Immunol. 1982;129:954-958.

51. Scheper RJ, Ans CHM, Dinther-Janssen V, et al. Specific accumulation of hapten-reactive $\mathrm{T}$ cells in contact sensitivity reaction sites. J Immunol. 1985;134:1333-1336.

52. Pehamberger H, Stingl LA, Pogantsch S, et al. Epidermal cell induced generation of cytotoxic $\mathrm{T}$ lymphocyte responses against alloantigens or TNP-modified syngeneic cells: requirement for Ia-positive Langerhans cells. J Invest Dermatol. 1983;81:208-211.

53. Tamaki K, Fujiwara H, Levy RB. Hapten-specific TNP-reactive cytotoxic effector cells using epidermal cells as targets. J Invest Dermatol. 1981;77:225-229.

54. Kalish RS, Morimoto C. Urushiol (poison ivy)-triggered suppressor $\mathrm{T}$ cell clone generated from peripheral blood. J Clin Invest. 1988;82:825-832.

55. Claman HN, Miller SD, Sy MS, et al. Suppressive mechanisms involving sensitization and tolerance in contact allergy. Immunol Rev. 1980;50:105-132.

56. Silberberg-Sinakin I, Thorbecke GJ, Baer RL, et al. Antigenbearing Langerhans cells in skin, dermal lymphatics and in lymph nodes. Cell Immunol. 1976;25:137-151.

57. Romani N, Koide S, Crowley M, et al. Presentation of exogenous protein antigens by dendritic cells to $T$ epidermal Langerhans cells. J Exp Med. 1989;169:1169-1178.

58. Sauder D, Tamaki K, Moshell A, et al. Induction of tolerance to topically applied TNCB using TNCB-conjugated ultraviolet light-irradiated epidermal cells. J Immunol. 1981;127:261263.

59. Noonan FP, Kripke ML, Pedersen GM, et al. Suppression of contact hypersensitivity in mice by ultraviolet irradiation is associated with defective antigen presentation. Immunology. 1981;43:527-533.

60. Toews G, Bergstresser P, Streilein J, et al. Epidermal Langerhans cell density determines whether contact hypersensitivity or unresponsiveness follows skin painting with DNFB. J Immunol. 1980;124:445-453.

61. Griffiths CE, Voorhees JJ, Nickoloff BJ. Characterization of intercellular adhesion molecule-1 and HLA-DR expression in normal and inflamed skin: modulation by recombinant gamma interferon and tumor necrosis factor. J Am Acad Dermatol. 1989;20:617-629.

62. Baadsgaard O, Hansen E, Elder JT, et al. UM4D4 the surface molecule of an antigen independent $\mathrm{T}$ cell activation pathway in psoriasis. New York: Alan R. Liss, Inc, 1989:469.

63. van Loveren $\mathrm{H}$, Meade R, Askenase PW. An early component of delayed-type hypersensitivity mediated by $\mathrm{T}$ cells and mast cells. J Exp Med. 1983;157:1604-1617.

64. Hancock GE, Kaplan G, Cohn ZA. Keratinocyte growth regulation by the products of immune cells. J Exp Med. 1988;168:1395-1402.
65. Lisby S, Baadsgaard O, Avnstorp C, et al. Irritant skin reactions demonstrate, in contrast to allergic reactions, decreased number and function of epidermal T6+DR+ Langerhans cells (abstract). J Invest Dermatol. 1988;91:405.

66. Gawkrodger DJ, McVittie E, Carr MN, et al. Phenotypic characterization of the early cellular responses in allergic and irritant contact dermatitis. Clin Exp Immunol. 1986;66:590-598.

67. Christensen OB, Daniels TE, Maibach HI. Expression of OKT6 antigen by Langerhans cells in patch test reactions. Contact Dermatitis. 1986;14:26-31.

68. Baadsgaard O, Lisby S, Avnstorp C, et al. Antigen-presenting activity of non-Langerhans epidermal cells in contact hypersensitivity reactions. Scand J. Immunol. 1990;32:217-224.

69. Basham TY, Nickoloff BJ, Merigan TC, et al. Recombinant gamma interferon induces HLA-DR expression on cultured human keratinocytes. J Invest Dermatol. 1984;83:88-90.

70. Volc-Platzer B, Majdic O, Knapp W, et al. Evidence of HLADR antigen biosynthesis by human keratinocytes in disease. $J$ Exp Med. 1984;159:1784-1789.

71. Lampert IA. Expression of HLA-DR (Ia like) antigen on epidermal keratinocytes in human dermatoses. Clin Exp Immunol. 1984;57:93-100.

72. Gaspari AA, Katz SI. Induction and functional characterization of class II MHC (Ia) antigens on murine keratinocytes. J Immunol. 1988;140:2956-2963.

73. Sy MS, Miller SD, Claman HN. Immune suppression with supraoptimal doses of antigen in contact sensitivity: I. demonstration of suppressor cells and their sensitivity to cyclophosphamide. J Immunol. 1977;119:240-244.

74. Tamaki K, Fujiwara H, Katz SI. The role of epidermal cells in the induction and suppression of contact sensitivity. J Invest Dermatol. 1981;76:275-278.

75. Miller SD, Claman HN. The induction of hapten-specific T cell tolerance by using hapten-modified lymphoid cells: I. characteristics of tolerance induction. J Immunol. 1978;117:15191526.

76. Kligman AM. Hyposensitization against rhus dermatitis. Arch Dermatol. 1958;78:47.

77. Sommer G, Parker D, Turk JL. Epicutaneous induction of hyporeactivity in contact sensitization: demonstration of suppressor cells induced by contact with 2-4-dinitrothiocyanatebenzene. Immunology. 1975;29:517-525.

78. Iijima M, Katz SI. Specific immunologic tolerance to dinitrofluorobenzene following topical application of dinitrothiocyanobenzene: modulation by suppressor T cells. J Invest Dermatol. 1983;81:325-330.

79. Gaspari A, Jenkins M, Katz SI. Class II MHC-bearing keratinocytes induce antigen-specific unresponsiveness in haptenspecific TH1 clones. J Immunol. 1988;141:2216-2220.

80. Robertson B, Gahring L, Newton R, et al. In vivo administration of interleukin 1 to normal mice depresses their capacity to elicit contact hypersensitivity responses: prostaglandins are involved in this modification of immune function. J Invest Dermatol. 1987;88:380-387.

81. Granstein RD, Lowy A, Greene MI. Epidermal antigen-presenting cells in activation of suppression: identification of a new functional type of ultraviolet radiation-resistant epidermal cell. J Immunol. 1985;132:563-565.

82. Granstein RD. Epidermal I-J bearing cells are responsible for transferable suppressor cell generation after immunization of mice with ultraviolet radiation-treated epidermal cells. J Invest Dermatol. 1985;84:206-209.

83. Breathnach SM, Katz SI. Thy-1+ dendritic cells in murine epidermis are bone marrow-derived. J Invest Dermatol. 1984;83:74-77.

84. Bergstresser P, Tigelaar RE, Dees JH, et al. Thy-1 antigen- 
bearing dendritic cells populate murine epidermis. J Invest Dermatol. 1983;81:286-288.

85. Bergstresser P, Tigelaar RE, Streilein JW. Thy-1 antigen bearing dendritic cells in murine epidermis are derived from bone marrow precursors. J Invest Dermatol. 1984;83:83-87.

86. Tschachler E, Schuler G, Hutterer J, et al. Expression of Thy-1 antigen by murine epidermal cells. J Invest Dermatol. 1983;81:282-285.

87. Koning F, Stingl G, Yokoyama WM, et al. Identification of a T3-associated gamma-delta $\mathrm{T}$ cell receptor on Thy-1+ dendritic epidermal cell lines. Science. 1987;236:834-837.

88. Stingl G, Konig F, Yamada H, et al. Thy-1+ dendritic epidermal cells express $\mathrm{T} 3$ and the $\mathrm{T}$-cell receptor gamma chain. Proc Natl Acad Sci USA. 1987;84:4586-4590.

89. Juziel WA, Takashima A, Bonyhadi M, et al. Regulation of $T$-cell receptor gamma-chain RNA expression in murine Thy-1+ dendritic epidermal cells. Nature. 1987;328:263-266.

90. Sullivan S, Bergstresser P, Tigelaar RE, et al. Induction and regulation of contact hypersensitivity by resident, bone marrow-derived, dendritic epidermal cells: Langerhans cells and Thy-1+ epidermal cells. J Immunol. 1986;137:2460-2467.

91. Shen HH, Talle MA, Goldstein G, et al. Functional subsets of human monocytes defined by monoclonal antibodies: a distinct subset of monocytes contain the cells capable of inducing the autologous mixed lymphocyte culture. J Immunol. 1983;130:698-705.

92. Smith JB, Knowlton RP. Activation of suppressor T cells in human autologous mixed lymphocyte culture. J Immunol. 1979;123:419-422.

93. James SP, Yenokida GG, Graeff AS, et al. Immunoregulatory function of T cells activated in the autologous mixed lymphocyte reaction. J Immunol. 1981;127:2605-2609.

94. Lisby S, Baadsgaard O, Cooper KD, et al. Decreased number and function of epidermal antigen presenting cells in the skin following application of irritant agents: relevance to cutaneous tumors? J Invest Dermatol. 1989;92:842-847.

95. Burrows WM, Stoughton RB. Inhibition of induction of human contact sensitization by topical glucocorticosteroids. Arch Dermatol. 1976;112:175-178.

96. Lynch DH, Gurish MF, Daynes RA. Relationship between epidermal Langerhans cell density ATPase activity and the induction of contact hypersensitivity. J Immunol. 1981; 126:1892-1897.

97. Larsson EL. Cyclosporine A and dexamethasone suppress $\mathrm{T}$ cell responses by selectively acting at distinct sites of the triggering process. J Immunol. 1980;124:2828-2833.

98. Aberer W, Stingl L, Pogantsch S, et al. Effect of glucocorticosteroids on epidermal cell-induced immune responses. J Immunol. 1984;133:792-797.

99. Ashworth J, Booker J, Breathnach SM. Effects of topical corticosteroid therapy on Langerhans cell antigen presenting function in human skin. Br J Dermatol. 1988;118:457-469.

100. Belsito DV, Flotte TJ, Lim HW, et al. Effect of glucocorticosteroids on epidermal Langerhans cells. J Exp Med. 1982;155:291-302.

101. Aberer G, Schuler G, Stingl G, et al. Ultraviolet light depletes surface markers of Langerhans cells. J Invest Dermatol. 1981;76:202-210.

102. Stingl G, Gazze-Stingl LA, Aberer W, et al. Antigen presentation by murine epidermal Langerhans cells and its alteration by ultraviolet B light. J Immunol. 1981;127:1707-1713.

103. Cooper KD, Neises GR, Katz SI. Antigen-presenting OKM5+ melanophages appear in human epidermis after ultraviolet radiation. J Invest Dermatol. 1986;86:363-370.

104. Cooper KD, Fox PF, Katz SI. Effects of ultraviolet radiation on human epidermal cell alloantigen presentation: initial depression of Langerhans cell function is followed by the appearance of T6-DR+ cells which enhance epidermal alloantigen presentation. J Immunol. 1984;134:129-137.

105. Baadsgaard O, Cooper KD, Lisby S, et al. Dose response and time course for induction of T6-DR+ human epidermal antigen presenting cells by in vivo UVA, UVB and UVC irradiation. J Am Acad Dermatol. 1987;17:792-800.

106. Baadsgaard O, Wulf HC, Wantzin GL, et al. UVB and UVC, but not UVA, potently induce the appearance of T6-DR+ antigen-presenting cells in human epidermis. J Invest Dermatol. 1987;89:113-118.

107. Morimoto C, Letvin N, Boyd A, et al. The isolation and characterization of the human helper inducer subset. J Immunol. 1985; 134:3762-3769.

108. Morimoto C, Letvin N, Distaso J, et al. The isolation and characterization of the human suppressor inducer $\mathrm{T}$ cell subset. J Immunol. 1985;134:1508-1515.

109. Baadsgaard O, Fox DA, Cooper KD. Human epidermal cells from ultraviolet light-exposed skin potently activate autoreactive $\mathrm{CD} 4+2 \mathrm{H} 4+$ suppressor-inducer lymphocytes and CD8+ suppressor/cytotoxic lymphocytes. J Immunol. 1988; 140:1738-1744.

110. Baadsgaard O, Salvo B, Mannie A, et al. In vivo ultraviolet-exposed human epidermal cells activate $T$ suppressor cell pathways that involve $\mathrm{CD}^{+}{ }^{+} \mathrm{CD} 4 \mathrm{SRA}^{+}$suppressor-inducer T cells. J Immunol. 1990;145:2854-2861.

111. Elmets A, Bergstresser P, Tigelaar RE, et al. Analysis of the mechanism of unresponsiveness produced by haptens painted on skin exposed to low-dose ultraviolet irradiation. J Exp Med. 1983;158:781-794.

112. Noonan FP, Bucana C, Sauder DN, et al. Mechanism of systemic immune suppression by UV irradiation in vivo. J Immunol. 1984;132:2408-2416.

113. Ellis CN, Gorsulowsky DC, Hamilton TA, et al. Cyclosporine improves psoriasis in a double-blind study. JAMA. 1986;256:3110-3116.

114. Hess AD, Tutschka PJ, Santos GW. Effect of cyclosporin A on human lymphocyte responses in vitro. J Immunol. 1981;126:961-968.

115. Reem GH, Cook LA. Gamma interferon synthesis by human thymocytes and $\mathrm{T}$ lymphocytes inhibited by cyclosporin $\mathrm{A}$. Science. 1983;221:63-65.

116. Shevach EM. The effects of cyclosporin A on the immune system. Ann Rev Immunol. 1985;3:397-423.

117. Orosz CG, Fidelus RK, Roopenian DC, et al. Analysis of cloned $\mathrm{T}$ cell function: $\mathrm{I}$. dissection of cloned $\mathrm{T}$ cell proliferative responses using cyclosporin A. J Immunol. 1982;129:1865-1868.

118. Leapman SB, Filo RS, Smith EJ, et al. In vitro effects of cyclosporin A on lymphocyte subpopulations. Transplantation. 1980;30:404-408.

119. Braida M, Knop J. Effect of cyclosporin A on the T-effector and $\mathrm{T}$-suppressor cell response in contact sensitivity. Immunology. 1986;59:503-507.

120. Nakagawa S, Oka D, Jinno Y, et al. Topical application of cyclosporine on guinea pig allergic contact dermatitis. Arch Dermatol. 1988;124:907-910.

121. Aldridge RD, Sewell HF, King G, et al. Topical cyclosporin A in nickel contact hypersensitivity: results of a preliminary clinical and immunohistochemical investigation. Clin Exp Immunol. 1986;66:582-589. 
This document is a scanned copy of a printed document. No warranty is given about the accuracy of the copy. Users should refer to the original published version of the material. 